\title{
THE EFFECTS OF USE VALUES, AMENITIES AND PAYMENTS FOR PUBLIC GOODS ON FARMLAND PRICES: EVIDENCE FROM POLAND*
}

\author{
Bazyli CZYZEWSKI - Radoslaw TROJANEK - Anna MATUSZCZAK
}

(Received: 22 November 2016; revision received: 19 May 2017; accepted: 19 November 2017)

The article contributes to the debate on how land prices are affected by production values, by farming subsidies and by environmental amenities. The authors carried out a comprehensive review of the literature on the actual determinants of land value and made an attempt to classify different approaches to this matter. Then they performed an empirical case study of the drivers of agricultural land values in a leading agricultural region of Poland. The aim of the study is to establish how the use values of land, amenities and policy payments contribute to land values in the Single Area Payment Scheme (SAPS), which operates in Poland. The study is based on a sample of 653 transactions during the years 2010-2013. A hierarchical regression (ML-IGLS method) was used, where the unobserved heterogeneity is attributed to the location-specific factors at different levels of analysis. Results indicate that the policy payments for public goods decapitalise the value of land, whereas the environmental amenities have a relatively strong influence on farmland prices.

Keywords: land value, policy incidence, public goods, environmental amenities

JEL classification indices: Q15, Q18, Q51

* The article was the outcome of the project funded by the National Science Centre, no. OPUS 6 UMO-2013/11/B/HS4/00572.

Bazyli Czyzewski, corresponding author. Associate Professor at the Department of Education and Personnel Development and Researcher in the Department of Macroeconomics and Agricultural Economics, Poznan University of Economics and Business, Poland.

E-mail: b.czyzewski@ue.poznan.pl

Radoslaw Trojanek, Assistant Professor at the Department of Microeconomics, Poznan University of Economics and Business, Poland. E-mail: r.trojanek@ue.poznan.pl

Anna Matuszczak, Associate Professor at the Department of Macroeconomics and Agricultural Economics, Poznan University of Economics and Business, Poland.

E-mail: anna.matuszczak@ue.poznan.pl 


\section{INTRODUCTION}

In the context of the European Union's Common Agricultural Policy (CAP), the impact of agricultural policy and subjective valuation of certain attributes of landed property (such as location, shape of the plot, proximity of forests, etc.) is different under the Single Area Payment Scheme (SAPS), which operates in the countries of Central-Eastern Europe than under the Single Payment Scheme (SPS) implemented in the Western European countries (since 2015 called Basic Payment Scheme - BPS). The basic differences between BPS and SAPS are that in the latter there are no disposable entitlements to payments, and every hectare of land fulfilling specified conditions receives the same subsidy (basic and supplementary). Thus in addition to the single area payment, a land user may additionally receive other supplementary payments of predefined amount - for example, for cereal production in Less Favoured Areas (LFA) and on account of environment subsidies. Theoretically, the right to subsidies belongs to the user of agricultural land, but in Polish practice, they are generally taken over by the landowners. Landowners usually persuade farmers to not apply for area payments by offering them lower rental fee in return. Considering the subsidy for each hectare as known, and as there is no limited pool of entitlements to payments, theoretically the market is capable to discount the incidence of agricultural policy on land prices well in advance. After 2004, as a result of Poland's accession to the European Union (EU), the prices of land in all categories and locations rose sharply, and since then the land prices have continued a strong upward trend, discounting the expected subsidies. Although it is evident that limitations of land property rights are crucial for land value (Deininger - Feder 2009; Alston - Mueller 2010; Hidalgo et al. 2010; De Luca - Sekeris 2012; Orellano et al. 2015), it is not the case in Poland. The land market operated without significant barriers, because the regulations were mainly limited to the granting of the right of pre-emptive purchase to the government's Agricultural Property Agency (APA). This situation has changed in May 2016 when a new and very restrictive act regulating turnover of agricultural land came into force in Poland.

There is a need for further research into how land prices are affected by use (production) values, environmental amenities and by agricultural policy (Czyżewski - Poczta-Wajda 2017) in the Central-Eastern European countries. The authors have attempted to fill these gaps by carrying out a comprehensive literature review on the actual determinants of land value over the world. We believe there is a need to classify different approaches to this matter and to sum up their results. We also provide an empirical case study of the drivers of agricultural land values in a leading agricultural region of Poland. The aim of the study is to establish 
how the natural resources, the fertility of agricultural land and various types of subsidies contribute to land market values.

The public goods aspect is of increasing interest. Theoretically, there should not be any market mechanisms for land valuation. According to economic theory, the market alone is not capable of ensuring an optimum supply of public goods, always producing a deficit instead. However, not all types of CAP subsidies carry a tangible effect on public goods. The concept of a public good here is something of a generalisation. It not only includes utilities with the attributes of "nonrivalrous" and "non-excludable" - that is the so-called "pure public goods" - but also common goods. Although it is debatable whether support from the first pillar of the CAP leads to the creation of public and common goods, a certain step in this direction is provided by the principle of cross-compliance. Nonetheless a number of rural development programmes under the second pillar of the CAP undoubtedly lead to the creation of new common goods or care for the existing ones, for example in LFAs, which generally contain valuable natural features. We can therefore assume that the following have the attributes of public goods: agri-environmental payments, subsidies for LFAs, and area-based payments. We test hypotheses that 1 / these payments contribute to farm land value, being a way to valorise public goods, and $2 /$ the environmental amenities play a predominant role in creating land value in Wielkopolska province.

The paper is organised as follows: in the next section, we review different mechanisms of farmland value creation according to the classical and hedonic approaches. Then, we present the agriculture and land market in Wielkopolska province in the institutional context. In the methodology section, we construct a theoretical model based on hierarchical (multilevel) approach. The final sections contain results, discussion and general conclusions.

\section{HOW AGRICULTURAL USE VALUES, POLICY AND AMENITIES MIGHT CONTRIBUTE TO THE LAND VALUE}

\section{Agricultural use values versus policy in the classical approach}

The thesis that 'farmland values are intrinsically linked to farm-related returns' is not new and has been put forward by many authors before (e.g. Drozd - Johnson 2004).

In general, researchers support the thesis that there is a growing imbalance between farm use values and agricultural land prices resulting from the incidence of agricultural policies. According to many studies from the United States, farm programme payments increase farmland prices, which tend to be the main factor 
in the above-mentioned imbalance (Towe - Tra 2013; Ifft 2015). However, different government programmes would have differential effects on their capitalisation into farmland values. There is a strong evidence that decoupled payments have a larger impact than coupled payments linked to market conditions, according to the empirical results of Latruffe et al. (2008) and Latruffe - Le Mouël (2009). However, further findings of Karlsson - Nilsson (2013) suggest that the single farm payment measured at local and regional levels has no influence on farm prices. Although the farmers who directly receive decoupled payments pass on a considerable share of payments to landowners via increased farmland rental rates, and the payments do not capitalise in agriculture if the landowners are not farmers. Since the results regarding the policy incidence on land value are ambiguous, there is a need for further research in this area, especially in the case of SAPS, which has not yet been examined.

\section{Amenities and urban-rural fringe in the hedonic approach}

The hedonic approach is probably the way of investigating the factors influencing real estate value that has been most explored in the literature (e.g. some recent studies: Deaconu et al. 2016; Trojanek - Gluszak 2017; Trojanek et al. 2017). In this approach, one does not focus on a specific type of value determinants (e.g. agricultural returns, rural subsidies, property rights), but considers all possible qualitative variables that count for a potential buyer at the transaction level. Hence, the area, soil quality, environmental "quality", agricultural practices, location of plots, distance and access to markets and the nearest city, and connectivity to roads have all been found to affect land values (Troncoso et al. 2010; Carreño et al. 2012; Leguizamón 2013), as well as land tenure (owned or rented), adoption of conservation practices, long-term land improvements, etc. (Abdulai et al. 2011; Choumert - Phélinas 2015).

As regards the urban-rural alternative use, Eagle et al. (2015) estimated that the urban development option contributes an average of $19 \%$ to agricultural land prices. For that reason, land from the Agricultural Land Reserve (ALR) without any development possibilities has a significantly lower market value. A strong and nonlinear relationship between land price and parcel size has been also observed, thus suggests that residential demand for ALR land has a large impact on the rural land market in the urban-rural fringe. Higher land value is also associated with land closer to cities (lower commuting costs) and with better touristic value (Borchers et al. 2014). Residential development pressure in the region is an incentive for shifting from active agriculture to rural estates or hobby farms with low productivity, profiting from reduced land values due to the ALR. Farms close 
to towns generate higher profits due to lower transportation costs to market, and they can offer some recreational opportunities as well as high-value land use activities, including residential use (Barnard 2000). Other authors explain farmland value in the vicinity of urban settlements by an inverse phenomenon to the gravity models, namely peri-urbanisation. This process consists of the spreading of cities into the surrounding countryside. The underlying mechanisms have been studied by many authors (Brueckner 2000; Cavailhès - Thomas 2013). The land market players anticipate capital gains from the development of farmland, and these gains are capitalised into land prices. (Much evidence points to land-intensive production systems in the neighbourhood of cities as a crucial factor explaining land prices.) However, there are also other explanatory variables significantly related to urban influence, such as population, commuting costs, income, distance to city centre, house prices, and accessibility (Livanis et al. 2006).

The incidence of the urban-rural fringe and peri-urbanization on agricultural land values is perceived as a result of incomplete markets for public and quasipublic goods. This conclusion was raised by Delbecq et al. (2014), who observed the impacts of agricultural and urban returns on farmland value.

Well-functioning farms can provide various public goods, such as biodiversity, climate regulation, rural culture and open space, as well as they can indirectly impact food quality and human health. Wasson et al. (2013) argue that the parcellevel attributes that comprise recreational and visual values are essential to explain agricultural land value.

Summing up we can develop the following general conclusions from the literature review: Agricultural policies create an imbalance between the farm income and the agricultural land values. Under SPS (BPS) a petrifaction of farmland structure occurs, and the land prices are not subjected to a long-term upward tendency. Under SAPS, since landowners apply a lower discount rate to cash flows from the decoupled payments, a growing demand for farmland occurs. However, further findings suggest that the decoupled payments do not influence farm prices when measured at local levels.

Meanwhile, land value is a negative exponential function of distance to large cities and the nearest city. Since residential land rents are much higher than farmland rents, the differences are capitalised into expected capital gains. Therefore near the urban settlements these gains are also captured in farmland prices, even when the plots are still used for agriculture.

Multiple researches have identified non-agricultural attributes of farmland contributing to its market value. It was shown to be a divergence between market value and agricultural use value when these attributes occur. In the following parts, we will test these statements for the representative sample of transactions from the Wielkopolska region in Poland. 


\section{WIELKOPOLSKA PROVINCE IN THE INSTITUTIONAL CONTEXT OF POLISH LAND MARKET}

So far the agricultural property management in Poland has been regulated by provisions of the civil code and by specific acts. These regulations did not, however, directly determine which conditions must be met by a citizen to become an owner of the agricultural property. Therefore, while any physical or legal person was entitled to this right, some entities were treated in a privileged way by the legal system. Such rules were in effect until May 2016, then a new and very restrictive act regulating turnover of agricultural land came into force in Poland. According to the new law, only individual farmers are entitled to buy agricultural land without limitations (providing the area is larger than $0.3 \mathrm{ha}$ ). Other entities need to obtain the consent of the President of the APA. The consent is granted if the seller proves that he took an attempt to offer the land to farmers but none of them was willing to buy it. We believe that such regulation is only temporary.

The principles of agricultural land purchase or lease in Poland should be divided into those that regulate the distribution of land included in the Agricultural Property Stock of the State Treasury (APSST), managed by the APA, and those that concern transactions between private entities. The regulations for private turnover of agricultural property are aimed at creating favourable conditions for the concentration of agricultural land ownership in the hands of entities active in agricultural production, particularly family farms. This premise is supported by the application of the right of pre-emption under the APA when selling agricultural property of a surface area that exceeds 5 ha. ${ }^{1}$ The APA has the pre-emption right to purchase land under the conditions provided by the agreement. The sale agreement is effective in the case where the agency does not declare willingness to exercise its right of pre-emption. So far the APA has used this right very rarely, but now, even though the APA has resigned from the pre-emption, the consent of APA President is needed to sell a piece of land to a non-farmer. According to the Act on Agricultural System, the pre-emption should prevent the speculation and excessive concentration of agricultural property. At the same time the management of the state agricultural land, which was included in the APSST is regulated in a special way. The provisions in this scope can be found in the State Treasury Agricultural Property Management Act, which aims at promoting sustainable uses of the state agricultural land. The Act regulates the way by which the state agricultural land can be managed. It defines a group of entities that are entitled to priority land purchase, and identifies the conditions for organising limited tenders (Czyżewski - Majchrzak 2014). According to the new law, the

In May 2017 the new government changed 5 ha to 0.3 . 
turnover of the land from the APSST is suspended for 5 years regarding the plots larger than 2 ha.

We also recall that in Poland there exist limitations on the purchase of agricultural property by foreigners. Citizens of the European Economic Area (EEA) member states can, without permission, purchase land they have leased for at least 3 to 7 years prior (depending on the voivodeship) and on which they conducted agricultural activities for the same duration as legal residents of Poland. The conditions with respect to obtaining permission from the minister in charge of Internal Affairs and Administration should have been subjected to further liberalisation during mid2016 but in fact it did not happen. To sum up, during the analysed period, the regulations remained relatively liberal despite the limits of private turnover of agricultural land. In the view of those regulations (before May 2016), one might expect a shift in land turnover from the state sector to the private sector. It was the case in Wielkopolska province. This statement can be supported by the following statistics:

In the years 2010-2013 individuals constituted $91 \%$ of farmland sellers, $3 \%$ of legal entities, $5 \%$ of the state and $1 \%$ of local authorities. If it is about buyers of farmland, individuals represented $98 \%$ of them, legal entities $1.5 \%$ and local authorities less than $0.5 \%{ }^{2}$ Therefore the average area of purchased land was quite small, around 3.8 ha (for more descriptive statistics see Table 2).

Wielkopolska is considered to be a leading region in terms of agricultural production, agro-technology and the development of agribusiness with $15 \%$ of Polish agricultural output, including $10 \%$ of crop output and $20 \%$ of animal output, whereas average total output per Polish region is about $7 \%$. The region takes the leading position in the production of slaughter livestock with $22 \%$ share in the country. The region also produces major crops, sugar beets and a significant amount of rapeseed. The cultivation area of outdoor field vegetables is also higher than the national average. The average area of Utilised Agricultural Area (UAA) per farm is 13 ha in Wielkopolska. The farmers cultivate about 1.8 million ha of farmland. Apart from all these assets, what needs to be emphasised is the innovative character of farmers in Wielkopolska. There are 163 thousand farms in the region. Almost $72 \%$ of them constitute farms up to 10 ha, that is relatively small in size and not very strong in terms of economics. However, Wielkopolska has developed a large group of modern farms, where the production technologies applied are of the same level as applied at the best European farms (Marshal Office of Wielkopolska 2017). Hence, this region ensures a full cross-section of the attributes affecting land prices. Relations between demand and supply in the market for agricultural land in Wielkopolska can be described by the term "land hunger".

Own calculations based on the data from registers of features and values of properties maintained by county authorities.) 


\section{METHODOLOGY FOR MULTILEVEL MODELLING}

As indicated in the literature review, in the studied population the problem of clustering arises (so-called "spatial heterogeneity"), and price functions may have a different position and gradient depending on the type of rural areas they relate to (for example, pro-environmental subsidies are capitalised in the value of land differently in tourist regions than in typical agricultural regions). Therefore, in the study, a random quota-based selection was made to obtain a sample of 653 agricultural land transactions during a four-year period (approximately $10 \%$ of all transactions in the area studied), proportional to the prevalence of each of four types of rural areas (described below) in the Wielkopolska region in Poland. The databases were elaborated on the basis of information from registers of features and values of properties maintained by county (powiat) authorities, land register information from the National Geoportal, and agricultural soil maps from the Provincial Geodetic and Cartographic Repository.

As noted above, four types of rural areas were distinguished based on a typology developed for Wielkopolskie province :

- Rural areas (poviats) integrated with a city, characterised by the fact that they are closest to the core city, growing and losing their typical rural character and taking on the status of informal urban neighbourhoods. In this way, their agricultural functions disappear, and income of most of the population comes from non-agricultural sources.

- Areas of competitive agriculture, with economically strong farms provide the primary source of income for the population (often featuring mixed agriculture). These areas have lower population density than the city-integrated areas. The areas include small towns and villages as an integral part, and provide administrative and supply services to agriculture.

- Economically peripheral areas, where farms with low economic power are predominant, are characterized by high levels of long-term and hidden unemployment, poverty and social exclusion. In these areas, the condition of the technical, economic and social infrastructure is poor and continues to decline further. Also, the population density is low and still decreasing.

- Agro-touristic areas, with large areas of forests, lakes and valuable natural resources possess a well-developed infrastructure for rural tourism. Recreational values (environmental rent) undoubtedly increase the value of agricultural land here. A significant proportion of the land (approximately 20\%) constitutes Natura 2000 areas, including landscape parks, national parks and forests.

In a situation where the hierarchical (clustering) problem arises, classical regression may lead to erroneous conclusions. Within the studied sample of transactions, several explanatory grouping variables form a multilevel hierarchy of factors which 
affect the land values. At the lowest level the location-specific factor for small areas called "agricultural complex type", which reflects the soil quality and type, agricultural use (arable land, meadow, forest) and crop yield. In the impact hierarchy the second-level location-specific factor, "the gmina" is the basic unit of local administration in Poland, reflects some geographical, social and local government conditions. At the third level the factor characterized as rural area type, is differentiated by land function. The most effective method of solving the problems of clustering is to construct a random effects coefficient regression model, that is, to use multilevel modelling or to evaluate separate models for each cluster (Czyżewski - Trojanek 2016a, 2016b). In our model, we assume that both the free term and regression coefficients for all the variables are random. We constructed the following regression model (Equation 1) and then estimated it using the maximum likelihood (ML) method, defined as IGLS (Iterative Generalised Least Squares):

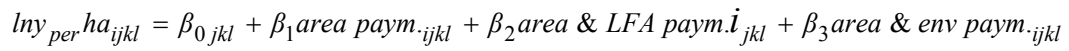

$$
\begin{aligned}
& +\beta_{4} \text { area \& LFA \& env paym } . i j k l_{i}+\beta_{5} \text { shape coeff }_{i j k l}+\beta_{6} \text { dist.to buildings }_{i j k l} \\
& +\beta_{7} \text { dist.to }_{\text {city }}{ }_{i j k l}+\beta_{8} \text { surface }_{i j k l}+\beta_{9} \text { building possibilities }_{i j k l} \\
& +\beta_{10} \text { asphalt road prox } i j k l+\beta_{11} \text { year_2010 }{ }_{i j k l}+\beta_{12} \text { year } \_2011_{i j k l}+\beta_{13} \text { year } \_2012_{i j k l}+e_{i j k l} \\
& \beta_{0 j k l}=\beta_{0}+f_{0 l}+v_{0 k l}+u_{0 j k l} \\
& \beta_{1 l}=\beta_{1}+f_{11}+v_{1 k l}+u_{1, k l} \\
& \beta_{2 l}=\beta_{2}+f_{2 l}+v_{2 k l}+u_{2 j k l} \\
& \ldots \\
& \beta_{131}=\beta_{13}+f_{13 l}+v_{13 k l}+u_{13, k l} \\
& {\left[\begin{array}{c}
f_{0 l} \\
f_{1 l} \\
\ldots \\
f_{13 l}
\end{array}\right] \sim N\left(0, \Omega_{f}\right): \Omega_{f}=\left[\begin{array}{cccc}
\sigma_{f 0}^{2} & - & - & - \\
\sigma_{f 01} & \sigma_{f 1}^{2} & - & - \\
\ldots & \ldots & \ldots & - \\
\sigma_{f 013} & \ldots & \sigma_{f 1213} & \sigma_{f 13}^{2}
\end{array}\right]} \\
& {\left[\begin{array}{c}
v_{0 k l} \\
v_{1 k l} \\
\ldots \\
v_{13 k l}
\end{array}\right] \sim N\left(0, \Omega_{v}\right): \Omega_{v}=\left[\begin{array}{cccc}
\sigma_{v 0}^{2} & - & - & - \\
\sigma_{v 01} & \sigma_{v 1}^{2} & - & - \\
\ldots & \ldots & \ldots & - \\
\sigma_{v 013} & \ldots & \sigma_{v 1213} & \sigma_{v 13}^{2}
\end{array}\right]} \\
& {\left[\begin{array}{c}
u_{0, j k l} \\
u_{1, j k l} \\
\ldots \\
u_{13, k l}
\end{array}\right] \sim N\left(0, \Omega_{u}\right): \Omega_{u}=\left[\begin{array}{cccc}
\sigma_{u 0}^{2} & - & - & - \\
\sigma_{u 01} & \sigma_{u 1}^{2} & - & - \\
\ldots & \ldots & \ldots & - \\
\sigma_{u 013} & \ldots & \sigma_{u 1213} & \sigma_{u 13}^{2}
\end{array}\right]} \\
& e_{i} j k l \sim N\left(0, \sigma_{e}^{2}\right)
\end{aligned}
$$


where:

$i$ - ordinal; $j$ - agricultural complex; $k$-administrative unit (gmina); $l$-type of rural area

$\sigma_{f 0}^{2} \ldots \sigma_{f 13}^{2}$ are the variances attributed to the endogenous variable " $l$ - type of rural area"

$\sigma_{v 0}^{2} \ldots \sigma_{v 13}^{2}$ are the variances attributed to the endogenous variable " $k$ - administrative unit (gmina)"

$\sigma_{u 0}^{2} \ldots \sigma_{u 13}^{2}$ are the variances attributed to the endogenous variable " $j$ - agricultural complex"

$\sigma_{f}, \sigma_{v}, \sigma_{u}$ are covariances, and $\Omega_{\mathrm{v}}$ is the matrix of variances and covariances.

The set of explanatory variables comprises (in the alphabetical order):

area paym. (ref. no payment) SAPS area payments only; dummy variable: yes/no; in SAPS area payments per ha are equal for each parcel which meets GEAC conditions;

area $\&$ LFA paym. (ref. no payment) SAPS area and LFA payments; dummy variable: yes/no; in SAPS LFA additional payments per ha are equal for each parcel;

area\&LFA\&env paym. (ref. no payment) SAPS area, LFA and environmental payments; dummy variable: yes/no; in SAPS additional environmental payments per ha are equal for each parcel participating in a given support programme; asphalt road prox. proximity of asphalt/dirt road; dummy variable: asphalt/dirt; building possibilities dummy variable: yes/no;

dist.to buildings distance to the nearest buildings $(\mathrm{km})$;

dist.to city distance to the nearest city $\mathrm{km}$;

$j$ land productivity coefficient: valuation according to type of agricultural complex, developed by The Institute of Soil Science and Plant Cultivation (IUNG), State Research Institute in Puławy (Poland), taking account of crop yield, soil quality and type (arable land, meadow, forest); a proxy for agricultural return; may also be treated as a lowest-level grouping variable;

$k$ administrative unit: a location-specific factor, reflecting such features as local authority actions, infrastructure and human capital, historical and geographical conditions; a grouping variable in multilevel analysis;

$l$ type of rural area: 4 types of area: integrated with a city, competitive agriculture, economically peripheral, agro-touristic. Each area type is a proxy for a specific set of land use attributes and rural amenities; a grouping variable in multilevel analysis;

shape_coeff.: shape and fragmentation coefficient calculated according to the formula $40 * \pi^{*}\left(\right.$ area/perimeter $\left.{ }^{\wedge} 2\right)$ including a fragmentation of plots (for the 
areas fragmented into three or more plots without any dominant plot the coefficient equals 0 );

surface area: total area of land purchased, in ha; year_2010-2013 (ref. 2013) dummy variable: yes/no.

The hierarchic approach allows us to take into account both the random free term and the nesting of random regression coefficients. The difference between classical (naive) and multilevel regression is the possible occurrence of random regressors $\beta_{1}, \beta_{2}, \ldots \beta_{13}$ and random free term $\beta_{0}$ due to the grouping of endogenous variables $j, k$, and $l$. This means that the regression functions of particular variables may have different slopes with regard to the type of agricultural complex (productivity class), administrative unit and/or functions of rural areas. In the classical model, the slope is assumed to be constant, which is a highly simplified assumption. The random regression coefficients make it possible to compute covariance and correlations between coefficients and covariance of coefficients and the free term. Therefore a model in this form enables the description of endogenous relationships.

In this approach, $\mathrm{R}^{2}$ is not calculated, and the fit of the model can be evaluated on a relative basis by comparing the statistic " $-2 \log$ likelihood" for successive versions of the model. Different researches of the authors show that this set of explanatory variables explains from $60 \%$ to $90 \%$ of the variation in land prices (for $\ln \mathrm{Y}$ ) in single-level OLS models for particular types of rural areas (Czyżewski - Trojanek 2016b).

There are several reasons for the choice of the log-linear function (Malpezzi 2003). Firstly, the log-linear model allows the added value to change proportionally to changes in the size and other attributes of the property. Secondly, the estimated regression coefficients are easy to interpret. The coefficient of a given variable may be defined as the percentage change in the value of land caused by a unit change in a value driver. Thirdly, the log-linear function often eases problems connected with the variability of a random component.

The decision on whether the introduction of a random free term and random regressors in the model is statistically significant was taken on the basis of a likelihood ratio test (LRT). All potential endogenous and exogenous variables were tested. We performed this on each occasion by calculating the difference between the " $-2 \log$ likelihood" statistics for the model with and without the random free term. This difference has a chi-square distribution with the number of degrees of freedom corresponding to the difference between the numbers of parameters estimated in the two models (Twisk 2006: 30-32). We repeated the procedure while deciding whether to introduce a random regression coefficient for further variables. High significance $(p<0.001)$ was found for the introduction of a ran- 
dom free term as a function of rural area type, administrative unit and agricultural complex and for one random coefficient, the "shape coefficient" variable as a function of rural area type (Equation 2 and 3 - see later).

In the following step, we evaluated the significance of the calculated regression coefficients using Wald's test that is dividing the coefficient obtained by its standard error and squaring the result. The statistic calculated in this way has a chi-square distribution with one degree of freedom. In log-linear regression the marginal effects are calculated as an EXP function for the estimated coefficients, interpreted as the percentage change in $\mathrm{Y}$ corresponding to a change in $\mathrm{X}$ by one unit (Equations 2 and 3).

Further, we computed the intra-class correlation coefficient (ICC) based on the variance of the free terms and the remaining residual variance. This coefficient shows what part of the unobserved heterogeneity of land prices can be attributed to grouping variables (location-specific factors) at particular levels. It is computed by dividing the intra-class variance by the total variance (Twist 2006: 32-33).

The linear multilevel analysis is a supplement to standard linear regression analysis. Hence the continuous output variable ought to have a normal distribution. Some tests show that this assumption is fulfilled at $p=0.05$, while others indicate that it is not (Table 1). The distribution of the dependent variable may therefore deviate slightly from normal, but this should not have a significant effect on the results. Descriptive statistics for the dependent variable and the independent ones are given in Tables 1 and 2, respectively, while the comparison of the estimated models is presented in Table 3.

Table 1. Descriptive statistics of the dependent variable

\begin{tabular}{c|c|c|c|c|c|r|c|c|c|c}
\hline Var. & $\begin{array}{c}\text { Valid } \\
\mathrm{N}\end{array}$ & Mean & Median & Min & Max & $\begin{array}{c}\text { Lower } \\
\text { Quartile }\end{array}$ & $\begin{array}{c}\text { Upper } \\
\text { Quartile }\end{array}$ & Std.Dev. & Coeff. Var. & Test for normality \\
\hline $\begin{array}{c}\text { Y price } \\
\text { (PLN)* }\end{array}$ & 653 & 102696.4 & 60000.0 & 8000.0 & 900000.0 & 32850.0 & 115000.0 & 127820.5 & 1.24 & $\begin{array}{r}\mathrm{W}=0.62890, \\
\mathrm{p}=0.0000\end{array}$ \\
\hline Y per ha & 653 & 25937.2 & 23676.48 & 5044.1 & 115175.8 & 15384.6 & 31791.9 & 15559.3 & 0.60 & $\begin{array}{r}\mathrm{W} * *=0.83342, \\
\mathrm{p}=0.0000\end{array}$ \\
\hline $\begin{array}{c}\text { Ln Y } \\
\text { per ha }\end{array}$ & 653 & 10.0 & 10.07 & 8.5 & 11.7 & 9.6 & 10.4 & 0.5 & 0.05 & $\begin{array}{r}\mathrm{W}=0.99306, \\
p=0.00402 \\
\text { K-S*** }=0.04520, \\
p<0.15\end{array}$ \\
\hline
\end{tabular}

Notes: *average exchange rate $€ 1=4.17$ PLN; $* *$ Shapiro-Wilk test; ***Kolmogorov-Smirnof test. 
Table 2. Descriptive statistics of the explanatory variables

\begin{tabular}{l|rcrc}
\hline & Average & Min & Max & Standard deviation \\
\hline ara\&LFA paym & 0.36 & 0.00 & 1.00 & 0.48 \\
area paym. only & 0.35 & 0.00 & 1.00 & 0.48 \\
area\&env paym. & 0.05 & 0.00 & 1.00 & 0.23 \\
area\&LFA\&env paym. & 0.09 & 0.00 & 1.00 & 0.28 \\
areas of agroturistic type & 0.10 & 0.00 & 1.00 & 0.30 \\
areas of city integrated type & 0.25 & 0.00 & 1.00 & 0.43 \\
areas of competitive agriculture & 0.09 & 0.00 & 1.00 & 0.28 \\
areas of peripheral type & 0.56 & 0.00 & 1.00 & 0.50 \\
asphalt road & 0.37 & 0.00 & 1.00 & 0.48 \\
building possibilities & 0.36 & 0.00 & 1.00 & 0.48 \\
dist. to building (m) & 218.57 & 0.00 & 3860.00 & 459.53 \\
dist. to city (km) & 7.23 & 0.20 & 26.70 & 4.03 \\
land productivity coeff. & 46.05 & 0.00 & 94.00 & 22.42 \\
peripheral area & 0.57 & 0.00 & 1.00 & 0.50 \\
shape coeff. & 2.60 & 1.00 & 5.00 & 1.42 \\
surface area (ha) & 3.84 & 1.00 & 25.96 & 3.79 \\
without payment & 0.15 & 0.00 & 1.00 & 0.35 \\
year2010 & 0.17 & 0.00 & 1.00 & 0.37 \\
year2011 & 0.24 & 0.00 & 1.00 & 0.43 \\
year2012 & 0.28 & 0.00 & 1.00 & 0.45 \\
year2013 & 0.31 & 0.00 & 1.00 & 0.46
\end{tabular}

Source: Own elaboration based on data from registers of features and values of properties maintained by county (poviat) authorities, land register information from the National Geoportal, and agricultural soil maps from the Provincial Geodetic and Cartographic Repository.

Table 3. Fixed and random parts of the models

\begin{tabular}{l|c|c|c|c|c|c}
\hline & Model 2 & S.E. & $\begin{array}{c}\text { p-value/ } \\
\text { Corr }\end{array}$ & Model 3 & S.E. & $\begin{array}{c}\text { p-value/ } \\
\text { Corr }\end{array}$ \\
\hline Dependent var. & \multicolumn{6}{|c}{ Ln land price per ha } \\
\hline
\end{tabular}

Fixed Part

\begin{tabular}{l|c|c|c|c|c|c}
\hline cons & 10.248 & 0.093 & $0.000^{* * *}$ & 10.047 & 0.099 & $0.000^{* * *}$ \\
\hline area paym. & -0.011 & 0.066 & 0.871 & 0.018 & 0.065 & 0.784 \\
\hline area\&LFA paym. & -0.152 & 0.060 & $0.011^{* *}$ & -0.169 & 0.058 & $0.004^{* * *}$ \\
\hline area\&env paym. & 0.030 & 0.099 & 0.760 & 0.071 & 0.099 & 0.476 \\
\hline area\&LFA\&env paym. & -0.231 & 0.084 & $0.006^{* * *}$ & -0.214 & 0.081 & $0.008^{* * *}$ \\
\hline shape coeff. & 0.021 & 0.009 & $0.016^{* *}$ & 0.012 & 0.007 & $0.090^{*}$ \\
\hline dist. to buildings & -0.229 & 0.060 & $0.000^{* * *}$ & -0.280 & 0.053 & $0.000^{* * *}$ \\
\hline dist. to city & -0.025 & 0.006 & $0.000^{* * *}$ & -0.021 & 0.006 & $0.000^{* * *}$ \\
\hline surface area & 0.008 & 0.005 & 0.119 & 0.002 & 0.005 & 0.705 \\
\hline building possibilities & 0.046 & 0.044 & 0.293 & 0.063 & 0.043 & 0.150 \\
\hline
\end{tabular}


Table 3. cont.

\begin{tabular}{|c|c|c|c|c|c|c|}
\hline & Model 2 & S.E. & $\begin{array}{l}\text { p-value/ } \\
\text { Corr }\end{array}$ & Model 3 & S.E. & $\begin{array}{l}\text { p-value/ } \\
\text { Corr }\end{array}$ \\
\hline Dependent var. & \multicolumn{6}{|c|}{ Ln land price per ha } \\
\hline asphalt road prox. & 0.022 & 0.041 & 0.595 & -0.008 & 0.041 & 0.836 \\
\hline year_2010 & -0.118 & 0.060 & $0.051^{* *}$ & -0.155 & 0.059 & $0.008^{* * *}$ \\
\hline year_2011 & -0.092 & 0.053 & $0.083 *$ & -0.099 & 0.052 & $0.056^{*}$ \\
\hline year_2012 & -0.007 & 0.051 & 0.891 & -0.018 & 0.050 & 0.713 \\
\hline integrated areas & - & - & - & 0.305 & 0.063 & $0.000^{* * *}$ \\
\hline agrotouristic areas & - & - & - & 0.732 & 0.082 & $0.000^{* * *}$ \\
\hline competitive agr. areas & - & - & - & 0.531 & 0.133 & $0.000^{* * *}$ \\
\hline land productivity coeff. & - & - & - & 0.001 & 0.001 & 0.428 \\
\hline \multicolumn{7}{|c|}{ Random Part } \\
\hline \multicolumn{7}{|l|}{ Level: l type of rural area } \\
\hline cons variance & 0.054 & 0.025 & $* *$ & - & - & - \\
\hline $\begin{array}{l}\text { shape coeff./cons } \\
\text { covariance }\end{array}$ & -0.002 & 0.003 & $\begin{array}{l}\text { Corr: } \\
-0.260\end{array}$ & - & - & - \\
\hline shape coeff. variance & 0.0011 & 0.0006 & $* *$ & - & - & - \\
\hline \multicolumn{7}{|c|}{ Level: $k$ administrative unit (gmina) } \\
\hline cons variance & 0.000 & 0.000 & - & 0.061 & 0.023 & $* * *$ \\
\hline $\begin{array}{l}\text { shape coeff./cons } \\
\text { covariance }\end{array}$ & - & - & - & -0.006 & 0.003 & \begin{tabular}{|c} 
Corr: \\
-0.838 \\
$* *$
\end{tabular} \\
\hline shape coeff. variance & - & - & - & 0.0008 & 0.0006 & $* *$ \\
\hline \multicolumn{7}{|c|}{ Level: $j$ land productivity coefficient } \\
\hline cons variance & 0.023 & 0.012 & $* *$ & - & - & - \\
\hline \multicolumn{7}{|c|}{ Level: $i$ random residual term } \\
\hline e variance & 0.194 & 0.013 & - & 0.196 & 0.013 & - \\
\hline$-2 *$ loglikelihood: & \multicolumn{3}{|c|}{925.578} & \multicolumn{3}{|c|}{869.767} \\
\hline
\end{tabular}

Note: $* * *, * *, *$ significance levels at $1 \%, 5 \%, 10 \%$, respectively.

Source: Own computations using MLwiN 2.36 (Centre for Multilevel Modelling, University of Bristol).

\section{RESULTS AND DISCUSSION}

The market for agricultural land in the Wielkopolska region exhibits very high degree of variations: the average price of a purchased property was 103,000 Polish Zloty (PLN), median 60,000 PLN with a standard deviation of 128,000 PLN, and a coefficient of variation of 1.24. The price per hectare is less variable: its mean is 26,000 PLN (median 24,000 PLN) with standard deviation 16,000 PLN (coefficient of variation is 0.6 ). Neither of these two variables has a normal distribution (Shapiro-Wilk tests lead to rejection of the hypothesis of normality 
at $\mathrm{p}<0.0001$ ); they both exhibit right-handed asymmetry (strongly, in the case of prices per property). In the log-linear version of the model, however, the distribution of ln Y per ha is close to normal, as mentioned above (Table 1). It was also found that the set of explanatory variables at the transaction level, excluding the location-specific factors, explain the variation in prices per ha to a relatively small degree (the coefficient pseudo- $\mathrm{R}^{2}$ was below 0.3 ). This can be partially ascribed to speculation on the land market and the significant demand disequilibrium, but it is the three location-specific factors in this case that have a key impact: agricultural complex, administrative unit (gmina) and rural area type. The solution to this problem is therefore the use of hierarchical modelling.

We undertook an attempt to model land prices per ha, to make it easier to interpret the marginal effects of particular variables. In the first step, we computed the set of equations and variance/covariance matrices shown in Equation 2. Statistically significant variables are asterisked, and standard errors are in parentheses. There is also detailed description of fixed and random parts in Table 3.

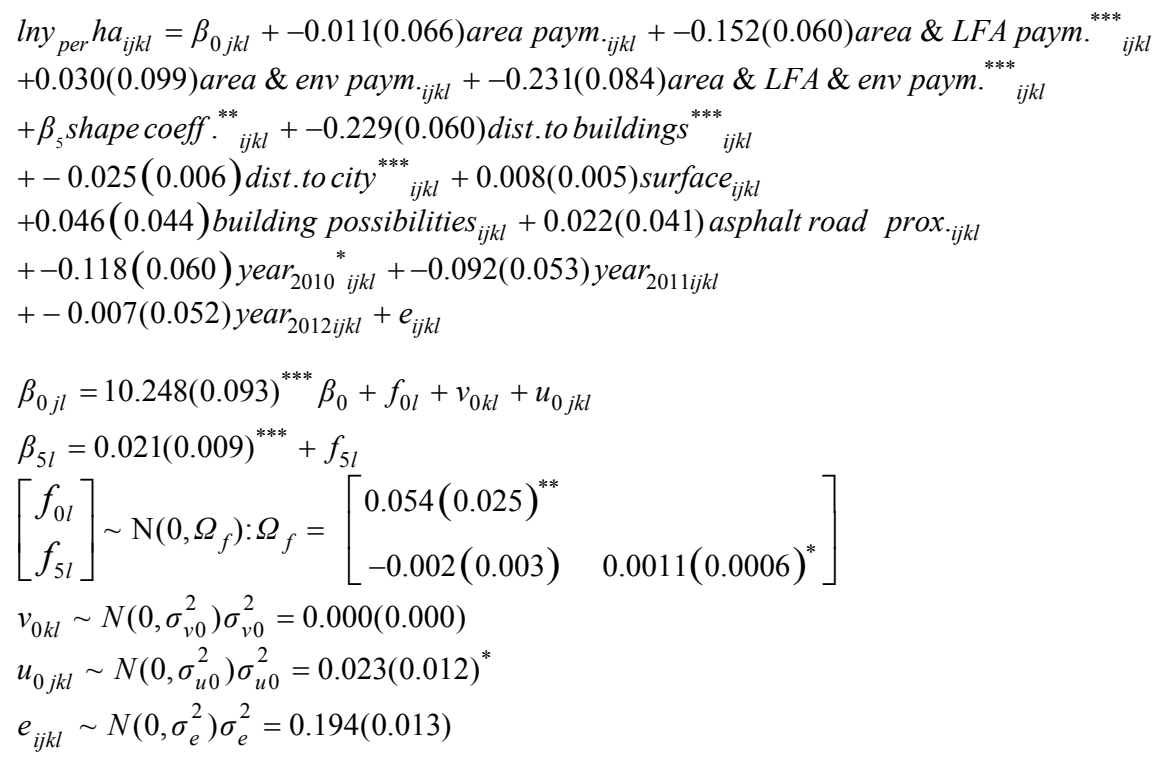

$-2 * \log$ likelihood $=925.578$ ( 653 of 653 cases in use, MLwiN, version 2.36.)

where: SE in parentheses; $\mathrm{i}$ - ordinal; 1 - type of rural area**; $k$-administrative unit (gmina); $j$ - agricultural complex**; ***p $<0.001,{ }^{* *} \mathrm{p}<0.05,{ }^{*} \mathrm{p}<0.1$

Statistical significance was found for the introduction of two levels of analysis, which was checked by comparing the statistic- $2 * \operatorname{loglikelihood~for~different~}$ 
model versions. The location-specific factor "type of rural area" is significant at $\mathrm{p}<0.05$, and "agricultural complex" $(j)$ is significant at $\mathrm{p}<0.1$. In this case the administrative unit (gmina) level proved insignificant. Moreover, the random regression coefficient for the shape coefficient significantly improves the fit of the model. The variable $f_{51}$ in the nested function is also statistically significant. We recall that the variable shape coeff. shall be important to explain the value of farmland since it comprises the fragmentation of land. In higher fragmented plots (lower shape coeff.), the agricultural use is more limited. We therefore computed the intra-class correlation coefficient (ICC) based on the variance of the free terms and the remaining residual variance for the significant levels of analysis, obtaining the value 0.284 . This means as much as $30 \%$ of the model's unobserved heterogeneity can be ascribed to the grouping variables: about $20 \%$ to the rural area type and about $10 \%$ to the "agricultural complex" (coefficient of land productivity). This is a relatively high value as in the single-level model the explanatory variables explained approximately $30 \%$ of the variation in prices per ha. Confirmation was thus obtained for the hypothesis that the location-specific factors are key drivers for land prices, with rural area type being the most significant factor.

Next, using Wald's test, we determined which of the explanatory variables are statistically significant. The figures in brackets are the standard errors for the regression coefficients. By computing the EXP function for particular coefficients, their marginal effect can be evaluated precisely. The analysis was performed with a division according to parcel-level attributes and the effect of agricultural policy (payments for public goods). Statistically significant attributes have the following marginal effects (EXP function for particular coefficients minus 1): improvement in the shape coefficient by one unit increases the price per ha by $2.1 \%$; an increase in distance to buildings by $1 \mathrm{~km}$ reduces the price per ha by $20.5 \%$; an increase in distance to the city by $1 \mathrm{~km}$ reduces the price per ha by $2.5 \%$; transactions concluded in 2010 had a price per ha lower by $10.9 \%$ than in 2013 ; transactions concluded in 2011 had a price per ha lower by $9.4 \%$ than in 2013; and transactions concluded in 2012 had a price per ha lower by 1.8\% than in 2013.

Statistically significant policy variables were found for additional LFA payments and sustainable support combining single area payment and LFA with agri-environmental payments (area\&LFA and area\&LFA\&env), but their marginal effects are negative: receipt of additional LFA payments reduces the price per hectare by $15.5 \%$, while ES reduces it by $19.3 \%$. This shows that the limitations on farming use (both natural and enforced by the CAP) associated with the receipt of these payments might have a negative effect on land rent and restrict possibilities of earning.

The direction of influence is logical. The results imply that location, distance from the city and infrastructure are key factors for agricultural land prices and 
exert a much stronger marginal effect than the hedonic features contained in the shape coefficient. It is in the line with other researches which have identified land value as a negative exponential function of the distances to large cities and the nearest city with at least 10,000 residents (Tsoodle et al. 2007). Similar conclusions have been formulated based on gravity models which measure urban influence by dividing county population by the squared distance of a county from business districts, as well as including both population and real income in urban areas (Guiling et al. 2009).

The results are somewhat surprising and contradict popular opinions about the effect of agricultural policy on land prices in Poland. Firstly, the effect of separate single area payments (area paym.) is statistically insignificant which is in line with some findings for Western Europe. Under the BPS, farmers are required to maintain the area of land on which they claim their single payment in good agricultural and environmental condition. This requirement is termed as 'cross-compliance'. The land area to be maintained is equal to the average number of hectares declared by the farmer in the reference period of 2000-2002 for which they had received their single-payment entitlements. The cited authors argue that the 'cross-compliance' obligations are sufficient to prevent farms from changing their land market decisions due to the increase of overall wealth (land collateral) and easier provision of loans from banks (Rude 2000), although farmers' risk aversion decreases (Hennessy 1998; Koundouri et al. 2009). As a result the decoupled payments support on-farm investment and off-farm labour supply (Guyomard et al. 2004) rather than farmland purchases. Thus, one may anticipate a negligible impact of decoupling reform both on farmers' demand for land and on-land supply, since farmers who have acquired land in the reference period would be forced to maintain that level of land to satisfy the cross-compliance requirements (O'Neill - Hanrahan 2012), while they have few opportunities to gain additional entitlements. For that reason, a petrifaction of farmland structure under the BPS will occur, and land prices will not be subjected to a long-term upward tendency. Under the SAPS the land market situation is quite different for the new member countries in the EU-12. Farmers do not need any historical entitlements for payments because mere possession of land entitles them to receive subsidies. As a result, a growing demand for farmland occurs, especially in agricultural regions where the phenomenon of 'land hunger' arises. However, the basic area payments have been already discounted on land prices, considering that the subsidy for each hectare had been known in advance before the beginning of each CAP operating period.

The farm real estate accounts for more than $80 \%$ of the total value of the United States farm assets, being a principal source of collateral for farm loans (Nickerson et al. 2012). If this were the case, feedback demand for land would occur, boosting its prices (MacDonald et al. 2013). Breustedt - Habermann (2011) 
found evidence that a farmland bubble would occur if the collateral helped farmers obtain more or cheaper financing, amplifying an initial increase in land prices, with a land-related increase in wealth leading to higher borrowing to buy land, which further increases land prices and collateral (see also Rajan - Ramcharan 2012). These factors have caused dramatic increases in farmland values in the US, where from 2004 to 2012 nominal cropland values doubled (USDA-NASS 2012). Lowenberg-DeBoer - Boehlje (1986) showed that capital gains from farmland appreciation increase a farmer's collateral. But it is not the case in Poland because banks are not willing to accept land as collateral. However, the situation when farmers pass on a considerable share of payments to landowners via farmland rental rates or informal channels is very typical in Poland, and then the payments do not capitalise as cited by Karlsson - Nilsson (2013). Last two factors might be the reasons for the insignificant coefficient of the single area payment in the model. We also recall that the expectations to increase in land prices are already discounted, and in most places at present, single payment support is not a differentiating factor for land value.

Interesting conclusion is that the other payments (area\&LFA and area\&LFA\&env) might not compensate for the opportunity costs related to alternative ways of land use as it is expected in CAP assumptions. Although the finding is contradictory to the studies cited above, some authors came to the same conclusion. According to Nilsson - Johansson (2013), agricultural and environmental payments in Sweden have also a negative influence on land prices. They argue that municipalities receiving agri-environmental support have very sensitive environments which are difficult for cultivation. A similar conclusion was reached in a previous study by Rutherford et al. (1990).

However, these effects have to be interpreted with a caution. An additional discussion is needed on the potential misleading effect of an endogenous allocation of LFA and environmental payments. Are the land prices lower due to agri-environmental support, as it was stated by the cited authors, or is it because of the difficulty to cultivate? There is a logical shortcut in this reasoning. In our opinion, the estimated negative effects can be casual, but only to some extent. The allocation of environmental payments is based on some characteristics correlated with land prices. Let us discuss it with the example of the most popular environmental schemes in Wielkopolska (Greater Poland) region: "Package 1. Sustainable farming" and "Package 2. Protection of soil and water". The first one had very demanding (and costly) requirements which theoretically could affect the land price, i.e.: the obligation to maintain all the permanent grassland and landscape elements not used for agricultural purposes unchanged, the ban on the sewage sludge use, the ban on the resuming agri-technical treatments before 15 February and the obligation to have a 5-year agri-environmental plan. The sec- 
ond scheme similarly implemented the ban on agri-technical treatments before 1 March and the ban on using a mixture of plants consisting of only species of cereals (Ministry of Agriculture and Rural development 2016). We have to consider questions like; why farmers decided to apply for these payments and whether removing the payments would increase the price of the land? In Wielkopolska, there are not many natural obstacles to farming, the fertile plains dominate. However, one can find valuable ecosystems along the bends of rivers and close to wooded areas being wildlife refuges. They are usually covered by the Nature 2000 network, and it is very difficult to obtain a building permission for any new facilities there. If some agricultural plots are located in such areas, the easiest way to retrieve a land rent is applying for environmental payments. Then, the requirements of CAP programmes sustain the status quo and a land is perceived by investors as less valuable. So, without these payments, it would be more likely that some economic activities occur nearby, thus busting the land prices. Hence, we believe that in case of Poland the payments for public goods are probably too low and fail to perform their role of compensating for the opportunity costs of pro-environmental land use.

Considering that the model described in Equation 2 indicates rural area type as the key factor explaining variation in land prices, we computed a second model (Equation 3), including the four types of area in the set of explanatory variables. This was done to determine which types of the rural area most strongly drive land prices, and in what direction. As has already been mentioned, each type is linked to different use values and amenities of agricultural land. In the case of agro-touristic areas, these are chiefly touristic and recreational amenities, for city-integrated areas they are urban amenities, and for areas of competitive agriculture they chiefly use values (the effect of peripheral areas is contained in the free term). The model in Equation 3 shows their final effect on land prices:

$n y_{p e r} h a_{i k}=\beta_{0 k}+0.018(0.065)$ area paym $_{i j k}+-0.169(0.058)$ area \& LFA paym. ${ }^{* * *}{ }_{i k}$

$+0.071(0.099)$ area \& env paym ${ }_{i k}+-0.214(0.081)$ area \& LFA \& env paym. ${ }^{* * *}{ }_{i k}$

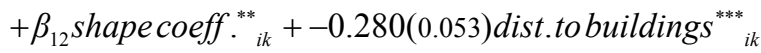

$+-0.021(0.006)$ dist.to city ${ }^{* * *}+0.002(0.005)$ surface $_{i k}$

$+0.063(0.043)$ building possibilities $Y E S_{i k}+0.008(0.041)$ asphaltroad prox $x_{i k}$

$+0.305(0.063)$ city integrated area ${ }_{i k}^{* * *}+0.732(0.082)$ agrotouristic area ${ }^{* * *}{ }_{i k}$

$+0.531(0.133)$ competitive area ${ }_{i k}^{* *}-0.115(0.059)$ year_2010 ${ }_{i k}^{* * *}$

$+-0.099(0.052)$ year_2011 ${ }^{* *}{ }_{i k}+-0.018(0.050)$ year_2012 ${ }_{i k}$

$+0.001(0.001)$ productivity coeff $_{i k}+e_{i k}$ 
$\beta_{0 k}=10.047(0.099)^{* * *}+v_{0 k}$

$\beta_{12 k}=0.012(0.007)^{*}+v_{12 k}$

$\left[\begin{array}{c}v_{0 k} \\ v_{12 k}\end{array}\right] \sim \mathrm{N}\left(0, \Omega_{f}\right): \Omega_{f}=\left[\begin{array}{cc}0.061(0.023)^{* * * *} & - \\ -0.006(0.003)^{* * *} & 0.0008(0.0006)\end{array}\right]$

$e_{i} k \sim N\left(0, \sigma_{e}^{2}\right) \sigma_{e}^{2}=0.196(0.013)$

$-2 * \operatorname{loglikelihood}=869,767$ (653 of 653 cases in use, MLwiN, version 2.36)

where: SE in brackets; $i$ - ordinal; $k$ - administrative unit (gmina); ***p $<$ $0.001,{ }^{* *} \mathrm{p}<0.05, * \mathrm{p}<0.1$

We can observe that it is recreational and touristic values that are most strongly capitalised in the price of land, since in these areas prices per hectare were more than twice as high as in the peripheral areas (exp 0.732). There are similar evidences for many areas throughout the US, the market value of farmland has exceeded its use value in agricultural production (Barnard 2000; Flanders et al. 2004). The latter, considering as the proxy of the areas of competitive agriculture, increased land prices by approximately $70 \%$, and urban amenities, which brought a $36 \%$ increase. Peripheral areas had a negative effect on land value. According to the above cited authors, amenity premiums also play a large role, for example, in Western Wyoming (US), where amenity values constitute $5 \%$ to $60 \%$ of a parcel's value (one-third on average).

In the overall evaluation, the model in Equation 3 has a better fit (the $-2 * \log$ likelihood value is significantly lower). The ICC shows that in this system the level of the gmina (administrative unit) explains approximately $24 \%$ of unobserved heterogeneity. Other conclusions, relating to the marginal effects of particular variables, are similar to those from the model in Equation 2. However, we can see an interesting endogenous effect in the significant covariance for the shape coeff. and constant (free) term with regard to the different administrative units $(k)$. It equals $-0,006$ whereas correlation coefficient amounts to -0.838 ( $\mathrm{Ta}$ ble 3). There are two ways of interpreting this: 1) the greater the effect of the shape and fragmentation, the smaller the "intrinsic value of the land" (Czyżewski - Matuszczak 2016) (assuming the free term is a proxy for intrinsic land value). Therefore, the logical interpretation is that the higher shape coeff. implies more intensive agricultural use; 2) the stronger local individual effects (due to the environmental amenities, for example), and the weaker the effect of production attributes on land price. 


\section{GENERAL CONCLUSIONS}

The variation in Polish agricultural land prices under SAPS is very large, as is likely the effect exerted on prices by speculation, which has driven the upward trend since the introduction of area payments in 2004. However, location-specific factors are of key importance, in particular "type of rural area" identified on the basis of land functions. Among the latter it is agro-touristic function that was relatively of the biggest importance, which means that recreational and touristic values are most strongly capitalised in the price of land. This supports the second hypothesis posed in the introduction. The computed models show that the type of rural area changes the position and gradient of the regression function. The area type determines the way in which hard-to-quantify use values such as culture, tradition and agro-technology, and amenities such as natural features, touristic infrastructure and urban transport, affect the price of land. Further, LFA and environmental payments have a relatively large (compared with other parcel-level attributes), but paradoxically negative effect on prices of agricultural land. These payments are capitalised in land prices only in peripheral areas. Elsewhere they do not perform their intended role, and indeed decapitalise the value of land, presumably due to the fact that they do not compensate for the opportunity costs related to alternative possibilities for obtaining land rent. This gives premises to reject the first hypothesis mentioned in the introduction because so called "payments for public goods" did not turn out to be the effective way to valorise land amenities. Considering the aims of the CAP, these schemes ought to be complementary, and not substitutive, with respect to the multifunctional development of the countryside, particularly in agro-touristic areas. As a result, policy makers in the EU member countries ought to reconsider changes to the structure and size of the second pillar of the CAP.

\section{REFERENCES}

Abdulai, A. - Owusu, V. - Goetz, R. (2011): Land Tenure Differences and Investment in Land Improvement Measures: Theoretical and Empirical Analyses. Journal of Development Economics, 96(1): 66-78.

Alston, L. - Mueller, B. (2010): Property Rights, Land Conflict and Tenancy in Brazil. NBER Working Paper, No. 15771.

Amacher, G. - Koskela, E. - Ollikainen, M. (2008): Deforestation and Land Use Under Insecure Property Rights. Environment and Development Economics, 14(3): 281-303.

Barnard, C. H. (2000): Agriculture and the Rural Economy: Urbanization Affects a Large Share of Farmland. Rural Conditions and Trends, 10(2): 57-63.

Bates, R. - Block, S. (2009): Political Economy of Agricultural Trade Interventions in Africa. Agricultural Distortions Working Paper, No. 87. 
Borchers, A. - Ifft, J. - Kuethe, T. (2014): Linking the Price of Agricultural Land to Use Values and Amenities. American Journal of Agricultural Economics, 96(5): 1307-1320.

Carreño, L. - Frank, F. C. - Viglizzo, E. F. (2012): Tradeoffs between Economic and Ecosystem Services in Argentina during 50 Years of Land-Use Change. Agriculture, Ecosystems \& Environment, 154: 68-77.

Cavailhès, J. - Thomas, I. (2013): Are Agricultural and Developable Land Prices Governed by the Same Spatial Rules? The Case of Belgium. Canadian Journal of Agricultural Economics, 61(3): 439-463.

Chatterjee, S. - Hadi, A. S. (2006): Regression Analysis by Example. $4^{\text {th }}$ ed. Hoboken: John Wiley\&Sons.

Choumert, J. - Phélinas, P. (2015): Determinants of Agricultural Land Values in Argentina. Ecological Economics, 110: 134-140.

Czyżewski, B. - Majchrzak, A. (2014): Regulations for the Polish Agricultural Land Market Compared with Other EU Member States: Implications for Market Efficiency. Studia Ekonomiczne, 2: $175-195$.

Czyżewski, B. - Matuszczak, A. (2016): A New Land Rent Theory for Sustainable Agriculture. Land Use Policy, 55: 222-229.

Czyżewski, B. - Przekota, G. - Poczta-Wajda, A. (2017): The Incidence of Agricultural Policy on the Land Market in Poland: Two-Dimensional and Multilevel Analysis. Land Use Policy, 63: 174-185.

Czyżewski, B. - Trojanek, R. (2016a): The Effects of Payments for Public Goods on Farmland Prices under SAPS. In: Czyżewski, B. (ed.): Political Rents of European Farmers in the Sustainable Development Paradigm. Warsaw: Polish Scientific Publishers, pp. 210-221.

Czyżewski, B. - Trojanek, R. (2016b): Czynniki wartości ziemi rolnej w kontekscie zróznicowanych funkcji obszarów wiejskich w Polsce (Drivers of Agricultural Land Prices in Terms of Different Functions of Rural Areas in Poland). Zagadnienia ekonomiki rolnej, 2: 3-24.

De Luca, G. - Sekeris, P.G. (2012): Land Inequality and Conflict Intensity. Public Choice, 150(1): $119-135$.

Deaconu, A. - Lazar, D. - Buiga, A. - Fatacean, G. (2016): Marginal Prices of Improvements Made to Blocks of Flats: Empirical Evidence from Romania. International Journal of Strategic Property Management, 20(2): 156-171.

Deininger, K. - Feder, G. (2009): Land Registration, Governance, and Development: Evidence and Implications for Policy. The World Bank Research Observer, 24(2): 233-266.

Drozd, D. J. - Johnson, B. B. (2004): Dynamics of a Rural Land Market Experiencing Farmland Conversion to Acreages: The Case of Saunders County, Nebraska. Land Economics, 80(2): 294-311.

Eagle, A. J. - Eagle, D. E. - Stobbe, T. E. - Van Kooten G. C. (2015): Farmland Protection and Agricultural Land Values at the Urban-Rural Fringe: British Columbia's Agricultural Land Reserve. American Journal of Agricultural Economics, 97(1): 282-298.

Flanders, A. - White, F. C. - Escalante, C. L. (2004): Equilibrium of Land Values from Agricultural and General Economic Factors for Cropland and Pasture Capitalization in Georgia. Journal of Agribusiness, 22(1): 49-60.

Guiling, P. - Brorsen, B. W. - Doye, D. (2009): Effect of Urban Proximity on Agricultural Land Values. Land Economics, 85(2): 252-264.

Guyomard, H. - Le Mouël, C. - Gohin, A. (2004): Impacts of Alternative Income Support Schemes on Multiple Policy Goals. European Review of Agricultural Economics, 31(2): 125-148.

Hennessy, D. A. (1998): The Production Effects of Agricultural Income Support Policies under Uncertainty. American Journal of Agricultural Economics, 80(1): 46-57. 
Hidalgo, F. D. - Naidu, S. - Nichter, S. - Richardson, N. (2010): Economic Determinants of Land Invasions. The Review of Economics and Statistics, 92(3): 505-523.

Ifft, J. - Kuethe, T. - Morehart, M. (2015): The Impact of Decoupled Payments on U.S. Cropland Values. Agricultural Economics, 46(5): 643-652.

Just, R. E. - Mirankowski, J. A. (1993): Understanding Farmland Price Changes. American Journal of Agricultural Economics, 75(1): 156-168.

Karlsson, J. - Nilsson, P. (2014): Capitalisation of Single Farm Payment on Farm Price: An Analysis of Swedish Farm Prices Using Farm-Level Data. European Review of Agricultural Economics, 41(2): 279-300.

Koundouri, P. - Laukkanen, M. - Myyrä, S. - Nauges, C. (2009): The Effects of EU Agricultural Policy Changes on Farmers' Risk Attitudes. European Review of Agricultural Economics, 36(1): 53-77.

Latruffe, L. - Doucha, T. - Le Mouël, C. - Medonos, T. - Voltr, V. (2008): Capitalisation of the Government Support in Agricultural Land Prices in the Czech Republic. Agricultural Economics, 54(10): 451-460.

Latruffe, L. - Le Mouël, C. (2009): Capitalization of Government Support in Agricultural Land Prices: What do We Know? Journal of Economic Surveys, 23(4): 659-691.

Leguizamón, A. (2013): Modifying Argentina: GM Soy and Socio-Environmental Change. Geoforum, 53: 149-160.

Lowenberg-DeBoer, J. - Boehlje, M. (1986): The Impact of Farmland Price Changes on Farm Size and Financial Structure. American Journal of Agricultural Economics, 68(4): 838-848.

MacDonald, J. - Korb, P. - Hoppe, R. (2013): Farm Size and the Organization of U.S. Crop Farming. Washington, D.C. U.S. Department of Agriculture, Economic Research Report, No. 152.

Malpezzi, S. (2003): Hedonic Pricing Models: A Selective and Applied Review. In: O'Sullivan, T. Gibb, K. (eds): Housing Economics and Public Policy: Essays in honor of Duncan Maclennan. Oxford: Blackwell, pp. 67-89.

Marshal Office of Wielkopolska (2017): https://www.umww.pl/agriculture, (accessed 16.03.2017.)

Ministry of Agriculture and Rural Development (2016): Agri-Environment-Climate Measure in Poland in the Context of Non-Double Funding. Proceedings of Workshop "Agri-Environmentclimate Measures (AECM): Challenges of Controllability and Verifiability “, 7th December, Brussels.

Orellano, V. - Azevedo, P. F. - Saes, M. S. - Nascimento, V. E. (2015): Land Invasions, Insecure Property Rights and Production Decisions. Journal of Agricultural Economics, 66: 660-671.

Rajan, R. - Ramchara, R. (2012): The Anatomy of a Credit Crisis: The Boom and Bust in Farm Land Prices in The United States in the 1920s. National Bureau of Economic Research Working Paper, No. 18027.

Rude, J. (2000): An Examination of Nearly Green Programs: Case Study for Canada. American Journal of Agricultural Economics, 82(3): 755-761.

Rutherford, T. F. - Whalley, J. - Wigle, R. M. (1990): Capitalization, Conditionality, and Dilution: Land Prices and the US Wheat Program. Journal of Policy Modeling, 12(3): 605-622.

Towe, C. - Tera, C. I. (2013): Vegetable Spirits and Energy Policy. American Journal of Agricultural Economics, 95(1): 1-16.

Trojanek, R. - Gluszak, M. (2017): Spatial and Time Effect of Subway on Property Prices. Journal of Housing and the Built Environment, 1: 1-26.

Trojanek, R. - Tanas, J. - Raslanas, S. - Banaitis, A. (2017): The Impact of Aircraft Noise on Housing Prices in Poznan. Sustainability, 9(11): 2088. 
Troncoso, J. L. - Aguirre, M. - Manriquez, P. - Labarra, V. - Ormazábal, Y. (2010): Influence of Physical Attributes on the Price of Land: The Case of the Province of Talca, Chile. Ciencia e Investigacion Agraria, 37(3): 105-112.

Tsoodle, L. J. - Featherstone, A. M. - Golden, B. B. (2007): Combining Hedonic and Negative Exponential Techniques to Estimate the Market Value of Land. Agricultural Finance Review, 67(2): 225-239.

Twisk, J. W. R. (2006): Applied Multilevel Analysis. Practical Guides to Biostatistics and Epidemiology. New York: Cambridge University Press.

U.S. Department of Agriculture (2012): National Agricultural Statistics Service.

Wasson, J. R. - McLeod, D. M. - Bastian, C. T. - Rashford, B. S. (2013): The Effects of Environmental Amenities on Agricultural Land Values. Land Economics, 89(3): 466-478. 